\title{
Pengaruh Kualitas Pelayanan terhadap Kepuasan Pelanggan Grab di Kota Palembang
}

\author{
Nadia Afrilliana ${ }^{1)}$ \\ 1) Universitas Muhammadiyah Palembang, Palembang, Indonesia
}

Email: nadiaafrilliana@ymail.com ${ }^{l)}$

\begin{abstract}
Abstrak
Tujuan dari penelitian ini untuk mengetahui rumusan masalah adakah pengaruh kualitas pelayanan terhadap kepuasan pelanggan Grab di Kota Palembang. Jenis penelitian yang digunakan adalah penelitian Asosiatif yaitu untuk mengetahui pengaruh kualitas pelayanan terhadap kepuasan pelanggan Grab di Kota Palembang. Variabel yang digunakan adalah Tangible, Reliability, Responsiveness, Assurance dan Empathy. Sampel dalam penelitian ini adalah sebanyak 68 responden, dengan teknik pengambilan sampel Purvosive Sampling. Data yang digunakan dalam penelitian ini adalah data primer, dengan menggunakan metode kuesioner. Teknik analisis yang digunakan adalah regresi linier berganda yang didapat $\mathrm{Y}=3,725+0,130 \mathrm{X}_{1}+0,255 \mathrm{X}_{2}+0,082 \mathrm{X}_{3}+0,273 \mathrm{X}_{4}-0,088 \mathrm{X}_{5}+\mathrm{e}$ Secara simultan (Uji F) ada pengaruh yang signifikan tangible, reliability, responsiveness, assurance dan empathy terhadap kepuasan pelanggan Grab di Kota Palembang. Secara parsial (Uji t) variabel tangible thitung $(2,609) \geq \mathrm{t}$ tabel $(1,666)$, variabel reliability thitung $(3,454) \geq t_{\text {tabel }}(1,666)$, variabel responsiveness thitung $(1,176) \leq t$ tabel $(1,666)$, variabel assurance nilai thitung $(3,235) \geq$ tabel $(1,666)$, dan variabel empathy thitung $(-0.985) \leq t_{\text {tabel }}(1,666)$, Koefisien Determinasi $\mathrm{R}^{2}$ sebesar 0,663 angka tersebut menggambarkan bahwa kepuasan pelanggan dapat dipengaruhi oleh kualitas pelayanan sebesar $66,3 \%$ sedangkan sisanya 0,337 atau $33,7 \%$ dijelaskan oleh variabel lain yang tidak termasuk dalam penelitian ini.
\end{abstract}

Kata Kunci: kualitas pelayanan, kepuasan pelanggan, pemasaran, perilaku konsumen

\begin{abstract}
The purpose of this study was to determine the problem formulation whether the effect of service quality on Grab customer satisfaction in Palembang City. This type of research is associative research, which is to determine the effect of service quality on Grab customer satisfaction in Palembang City. The variables used are Tangible, Reliability, Responsiveness, Assurance and Empathy. The sample in this study were 68 respondents, with purposive sampling technique as a sample. The data used in this study are primary data, using a questionnaire method. The analysis technique used is multiple linear regression obtained $\mathrm{Y}=.3,725+0.130 \mathrm{X} 1+0.255 \mathrm{X} 2+$ $0.082 \mathrm{X} 3+0.273 \mathrm{X} 4-0.088 \mathrm{X} 5+\mathrm{e}$ Simultaneously $(\mathrm{F}$ test) there is a significant effect of tangible, reliability, responsiveness, assurance and empathy on Grab customer satisfaction in Palembang City. Partially ( $t$ test) tangible variable t count (2.609) $\geq$ ttable (1.666), variable reliability tcount (3.454) $\geq$ ttable (1.666), variable responsiveness tcount $(1.176) \leq$ ttable $(1.666)$, assurance variable tcount $(3,235) \geq \mathrm{t}$ table $(1.666)$, and the empathy variable tcount $(-0.985) \leq$ ttable (1.666), the coefficient of determination R2 of 0.663 this figure illustrates that customer satisfaction can be influenced by service quality by $66.3 \%$ while the remaining 0.337 or $33.7 \%$ is explained by other variables not included in this study.
\end{abstract}

Keywords: service quality, customer satisfaction, marketing, consumer behavior

\section{Pendahuluan}

Pemasaran merupakan ilmu yang mempelajari bagaimana manusia memenuhi kebutuhan atau keinginannya sehingga merasa puas. Kebutuhan atau keinginan tersebut dipenuhi dengan cara membeli barang dan jasa. Mengingat banyaknya ragam barang atau jasa yang dapat di gunakan untuk memenuhi kebutuhan manusia maka dapat dibayangkan betapa luas dan kompleksnya aktifitas tersebut. Akibat kehidupan manusia yang berkembang maka barang dan jasa yang diinginkan manusia pun berkembang sehingga dinamika aktifitas pemasaran pun hampir tidak pernah berhenti. 
Salah satu kajian dari konsep pemasaran yang penting yaitu membahas tentang kepuasan pelanggan. Kepuasaan konsumen adalah perasaan senang kecewa seorang setelah membandingkan antara kinerja (hasil) produk yang dipikirkan terhadap kinerja yang diharapkan (Kotler dan Keller, 2008). Kepuasaan pelanggan juga merupakan sebuah tujuan usaha,karena kepuasan tersebut akan menimbulkan perilaku dimasa yang akan datang bagi usaha tersebut tidak akan dapat bertahan dan berkembang.

Jasa transportasi yang berbasis aplikasi online menyediakan pelayanan untuk membantu masyarakat melakukan rutinitas dalam meningkatkan efesiensi dan mobilitas yang padat. Jasa transportasi online adalah jasa yang memberikan pelayanan baik, namun dalam memahami kebutuhan dan kepuasan konsumen masih terbatas. Untuk dapat memenuhi kebutuhan konsumen, perusahaan harus mengikuti perkembangan teknologi. Persaingan antar jasa transportasi online banyak didasari pada sebuah bentuk teknologi yang lebih maju dan efisien bagi perusahaan jasa.

Wells dan Prensky (1996) dikutip pada buku Sudaryono (2016) menyatakan kepuasan atau tidak kepuasaan konsumen merupakan sikap konsumen terhadap suatu produk dan jasa sebagai hasil dari evalusi konsumen setelah menggunakan sebuan produk atau jasa. Konsumen akan merasa puas jika pelayanan yang diberikan produk ata jasa menyenangkan hati.

Menurut Fandy Tjiptono (2014) Kepuasan pelanggan adalah perasaan senang atau kecewa seseorang yang muncul setelah membandingkan antara persepsi terhadap kinerja (hasil) suatu produk dengan harapan-harapannya.

American society for qualty control (dikutip Fandy tjiptono, 2005) dikutif pada buku Danang Sunyoto (2012) menyatakan bahwa kualitas merupakan :"keseluruhan ciri serta,sifat barang dan jasa yang berpengaruh pada kemampuannya memenuhi kebutuhan yang dinyatakan maupun yang tesirat".

Menurut rambat lupiyoadi (2008) terdapat lima demensi service quality yaitu Bukti langsung (tangibles), Keandalan (reliability),Ketanggapan (responsiveness), Jaminan dan kepastian (asurance) dan Perhatian (empaty).

Ada lima dimensi yang dipakai untuk mengukur kualitas pelayanan, yaitu: Bukti Fisik (Tangible), meliputi fasilitas fisik, perlengkapan, pegawai dan sarana komunikasi, Keandalan (Reliability), yakni kemampuan memberikan layanan yang dijanjikan dengan segera, akurat, dan memuaskan, Daya Tanggap (Responsiveness), yaitu keinginan para staf untuk membantu para pelanggan dan memberikan layanan dengan tanggap, Jaminan (Assurance), mencakup pengetahuan, kompetensi, kesopanan, dan sifat dapat dipercaya yang dimiliki para staf; bebas dari bahaya, risiko atau keragu-raguan, Kepedulian/Empati (Empathy), meliputi kemudahan dalam menjalin relasi, komunikasi yang baik, perhatian pribadi, dan pemahaman atas kebutuhan individual para pelanggan.

Kepuasan pengguna jasa transportasi online untuk melakukan perjalanan dengan kualitas pelayanan terbaik dipengaruhi pengetahuan konsumen mengenai kualitas pelayanan di jasa transportasi online yang bersangkutan. Kualitas pelayanan mampu menciptakan image baik atau image buruk suatujasa transportasi online, karena pada dasarnya yang ditawarkan suatu jasa transportasi online adalah kualitas pelayanan dan kepuasan yang akan diberikan, adanya kepuasan konsumen mengenai jasa yang diterima akan mempengaruhi keinginan konsumen untuk melakukan penggunaan selanjutnya.

Kualitas layanan adalah permulaan dari kepuasan pelanggan. Pelanggan akan merasa puas, 
apabila mereka memperoleh pelayanan yang baik atau sesuai dengan yang diharapkan. Dengan demikian kualitas pelayanan terus ditingkatkan sehingga mencapai apa yang diharapkan oleh pelanggan maka akan puas. Seperti yang telah dikemukakan maka dapat diketahui bahwa kualitas layanan terhadap kepuasan pelanggan sangatlah penting untuk diperhatikan dan terus menerus dikontrol agar kinerja perusahaan jangan sampai berbeda dibawah pesaing. Pelanggan yang puas dapat meningkatkan keuntungan perusahaan serta mempertahankan kelangsungan hidup di dalam suatu persaingan.

Untuk meningktakan penghasilan maka yang harus diperhatikan oleh perusahaan ada pelayanan yang di baik kepada pelanggan sehingga konsumen merasak puas. Tapi pada kenyataannya masih ada para sopit grab memberikan pelayanan yang kurang memuaskan terhadap pelanggan seperti menjemput dan mengatar pelanggan maupun pesanan tidak tepat waktu, masih ada driver grab yang tidak menggunakan atribut (seperti menggunak jaket, maupun helm dari perusahaan), masih ada driver yang kurang memahami keinginan pelanggan.

\section{Tinjau pustaka}

\subsection{Kepuasan Pelanggan}

Menurut Kotler \& Keller (2009) kepuasan pelanggan adalah perasaan senang atau kecewa seseorang yang timbul karena membandingkan kinerja yang dipersepsikan produk (atau hasil) terhadap ekspetasi mereka.

Menurut Fandy Tjiptono (2019) kepuasan pelanggan merupakan elemen pokok dalam pemikiran dan praktik pemasaran modern. Persaingan dapat dimenangkan apabila perusahan mampu menciptakan dan mempertahankan pelanggan. Kuncinya terletak pada kemampuan memahami perilaku konsumen sasaran secara komprehensif, kemudian memanfaatkan pemahaman itu dalam merancang, mengkomunikasikan, dan menyampaikan program pemasaran secara lebih efektif dibandingkan para pesaing (Hildayanti \& Marnisah, 2018; Raka, Wadud, \& DP, 2020; Oktareza, Halin, \& Handayani, 2020; Amha, 2020)

Menurut Anderson dalam buku Fandy Tjiptono (2014) kepuasan pelanggan telah menjadi konsep sentral dalam teori dan praktik pemasaran, serta merupakan salah satu tujuan esensial bagi aktivitas bisnis. Kepuasan pelanggan berkontribusi pada sejumlah aspek krusial, seperti terciptanya loyalitas pelanggan, meningkatnya reputasi perusahaan, berkurangnya elastisitas harga, berkurangnya biaya transaksi masa depan, dan meningkatnya efisiensi dan produktivitas karyawan (Aprianto, 2016; Yanti, Karir, \& Wadud, 2018; Wadud, 2018; Pribadi, 2020; Nugraha \& Sumadi, 2020; Siswanto, Adhilla, \& Purwoko, 2020).

Pengukuran tingkat kepuasan pelanggan, ada beberapa aspek penting yang saling berkaitan. Meskipun demikian, ditengah beragamnya cara mengukur kepuasan pelanggan. Menurut Fandy Tjiptono (2014), terdapat enam konsep inti apa yang harus diukur dari kepuasan pelanggan tersebut yaitu:

1) Kepuasan Pelanggan Keseluruhan (Overall Customer Satisfaction) merupakan cara yang paling sederhana untuk mengukur kepuasan pelanggan adalah langsung menanyakan kepada pelanggan seberapa puas mereka dengan produk atau jasa spesifik tertentu.

2) Dimensi Kepuasan Pelanggan

Yaitu penelitian memilah kepuasan pelanggan ke dalam komponen-komponennya. Umumnya proses semacam itu terdiri dari atas empat langkah. Berupa, mengidentifikasi dimensi-dimensi kunci kepuasan pelanggan, meminta pelanggan menilai produk atau jasa 
perusahaan berdasarkan item-item spesifik seperti kecepatan layanan atau keramahan staf layanan pelanggan, meminta pelanggan menilai produk atau jasa pesaing berdasarkan itemitem spesifik yang sama dan meminta mereka paling penting dalam menilai kepuasan pelanggan keseluruhan.

3) Konfirmasi Harapan (Confirmation of Expectations)

Dalam konsep ini, kepuasan tidak diukur langsung, namun disimpulkan berdasarkan kesesuaian atau ketidaksesuaian antara harapan pelanggan dengan kinerja aktual produk perusahaan.

4) Niat Beli Ulang (Repurchase Intention)

Yaitu kepuasan pelanggan diukur secara behavioral dengan jalan menanyakan apakah pelanggan akan berbelanja atau menggunakan jasa perusahaan lagi.

5) Kesediaan untuk merekomendasi (Willingness to Recommend) Kesediaan pelanggan untuk merekomendasikan produk kepada teman atau keluarganya menjadi ukuran yang penting untuk dianalisis dan ditindak lanjuti.

6) Ketidakpuasan Pelanggan (Customer Dissatisfaction)

Dilihat dari beberapa macan aspek yang sering ditelaah guna mengetahui ketidakpuasan pelanggan, meliputi komplain, retur atau pengembalian produk, biaya garansi, recall, word of mount dan defections (konsumen yang beralih ke pesaing)

Menurut Pratiwi (2014) menyatakan kunci untuk mempertahankan pelanggan adalah kepuasan pelanggan, indikator kepuasan pelanggan dapat dilihat dari:

1) Kesesuaian harapan, merupakan tingkat kesesuaian harapan antara kinerja produk yang diharapkan oleh pelanggan dengan yang dirasakan oleh pelanggan, meliputi: (a) Produk yang diperoleh sesuai atau melebihi dengan yang diharapkan; (b) Pelayanan oleh karyawan yang diperoleh sesuai atau melebihi dengan yang diharapkan; (c) Fasilitas penunjang yang didapat sesuai atau melebihi dengan yang diharapkan.

2) Minat berkunjung kembali, merupakan kesediaan pelanggan untuk berkunjung kembali atau melakukan pembelian ulang terhadap produk terkait, meliputi: (a) Berminat untuk berkunjung kembali karena pelayanan yang diberikan oleh karyawan mamuaskan; (b) Berminat untuk berkunjung kembali karena nilai dan manfaat yang diperoleh setelah mengkonsumsi produk; (c) Berminat untuk berkunjung kembali karena fasilitas penunjang yang disediakan memadai.

3) Kesediaan merekomendasikan, merupakan kesediaan pelanggan untuk merekomendasikan produk yang telah dirasakannya kepada teman atau keluarga, meliputi: (a) Menyarankan teman atau kerabat untuk membeli produk yang ditawarkan karena pelayanan yang memuaskan; (b) Menyarankan teman atau kerabat untuk membeli produk yang ditawarkan karena fasilitas penunjang yang disediakan memadai; dan (c) Menyarankan teman atau kerabat untuk membeli produk yang ditawarkan karena nilai atau manfaat yang didapat setelah mengkonsumsi sebuah produk.

\subsection{Kualitas Pelayanan}

Kata kualitas mengandung banyak definisi dan makna karena orang yang berbeda dan akan mengartikannya secara berlainan, seperti kesesuaian dengan persyaratan atau tuntutan, kecocokan untuk pemakaian perbaikan berkelanjutan, bebas dari kerusakan atau cacat, 
pemenuhan kebutuhan pelanggan, melakukan segala sesuatu yang membahagiakan. Definisi kualitas pelayanan berpusat pada upaya pemenuhan kebutuhan dan keinginan pelanggan serta ketepatan penyampaiannya untuk mengimbangi harapan pelanggan. Goeth dan Davis yang dikutip Fandy Tjiptono (2018) bahwa kualitas merupakan suatu kondisi dinamis yang berhubungan dengan produk, jasa, manusia, proses, dan lingkungan yang memenuhi atau melebihi harapan. Sebaliknya, definisi kualitas yang bervariasi dari yang kontroversional hinnga kepada yang lebih strategis.

Menurut Rambat Lupiyoadi (2016) lima dimensi pokok kualitas pelayanan yang dikenal dengan SERVQUAL (service quality) yang terdiri dari:

\section{1) Bukti Fisik (Tangible)}

Kemampuan suatu perusahaan dalam menunjukkan eksistensinya kepada pihak eksternal. Penampilan dan kemampuan sarana dan prasarana fisik perusahaan yang dapat diandalkan serta keadaan lingkungan sekitarnya merupakan salah satu cara perusahaan jasa dalam menyajikan kualitas layanan terhadap pelanggan. diantaranya meliputi fasilitas fisik (gedung, buku, rak buku, meja dan kursi, dan sebagainya), teknologi (peralatan dan perlengkapan yang dipergunakan), serta penampilan pegawai.

2) Kehandalan (Reliability)

Kemampuan perusahan memberikan pelayanan sesuai dengan apa yang dijanjikan secara akurat dan terpercaya. Kinerja harus sesuai dengan harapan pelanggan yang tercermin dari ketepatan waktu, pelayanan yang sama untuk semua pelanggan tanpa kesalahan, sikap simpatik dan akurasi yang tinggi.

3) Daya Tanggap (Responsiveness)

Kemampuan untuk membantu pelanggan dan memberikan jasa dengan cepat dan tepat dengan penyampaian informasi yang jelas. Mengabaikan dan membiarkan pelanggan menunggu tanpa alasan yang jelas menyebabkan persepsi yang negative dalam kualitas pelayanan.

4) Jaminan (assurance)

Pengetahuan, kesopan-santunan dan kemampuan para pegawai perusahaan untuk menumbuhkan rasa percaya para pelanggan kepada perusahaan.

\section{5) Empati (Empathy)}

Memberikan perhatian yang tulus dan bersifat individual atau pribadi yang diberikan kepada pelanggan dengan berupaya memahami keinginan konsumen dimana suatu perusahaan diharapkan memiliki suatu pengertian dan pengetahuan tentang pelanggan, memahami kebutuhan pelanggan secara spesifik, serta memiliki waktu pengoprasian yang nyaman bagi pelanggan.

\section{Metode Penelitian}

Jenis penelitian yang digunakan dalam penelitian ini adalah penelitian asosiatif. Menurut Sugiyono (2017) Penelitian asosiatif merupakan penelitian yang bermaksud menggambarkan dan menguji hipotesis hubungan dua variabel atau lebih. Berdasarkan Perhitungan rumus conchran menurut Sugiyono sampel yang didapat sebanyak 68 responden dalam penelitian ini.

Metode pengumpulan data yang digunakan dalam penelitian ini yaitu kuesioner (Angket). 
Menurut Sugiyono (2017) Kuisioner (angket) adalah cara pengumpulan data dengan menggunakan daftar pertanyaan (angket) atau daftar isian terhadap objek yang diteliti.

Analisis data yang digunakan dalam penelitian ini adalah kualitatif yang dikuantitatifkan (Sugiyono 2016). Hasil Penelitian Menggunakan Analisis Regresi Linier Berganda Menurut Sugiyono (2017) regresi linear berganda adalah pengembangan dari regresi linear sederhana, yaitu sama-sama alat yang digunakan untuk memproduksi permintaan di masa akan datang berdasarkan data masa lalu untuk mengetahui pengaruh satu atau lebih variabel bebas (independent) terhadap satu variabel tak bebas (dependent). Pengujian Hipotesis Secara Bersama-sama (Uji F) Uji F digunakan untuk menguji variabel-variabel secara keseluruhan atau secara bersama-sama terhadap kepuasan Pelanggan. Pengujian Hipotesis Individual (Uji t). Uji $\mathrm{t}$ digunakan untuk menguji pengaruh tangible, reliability, responsiveness, assurance dan empathy secara parsial terhadap kepuasan pelanggan.

\section{Pembahasan}

Pada bab hasil dan pembasahan ini peneliti akan menjabarkan dan menggambarkan tentang temuan dari penelitian. Berdasarkan hasil wawancara yang telah dilakukan, peneliti memperoleh beberapa hasil data yang kemudian peneliti uraikan dalam bentuk pembahasan. Data Penelitian berisikan tentang adakah pengaruh Kualitas Pelayanan Terhadap Kepuasan Pelanggan. Hasil Penelitian Ini dapat dilihat dari hasil uji analisi data sebagai berikut:

\subsection{Analisis Regresi Linier Berganda}

Tabel 1. Hasil Analisis Regresi Linier Berganda

\begin{tabular}{|c|c|c|c|c|c|c|}
\hline \multirow{2}{*}{\multicolumn{2}{|c|}{ Model }} & \multicolumn{2}{|c|}{$\begin{array}{l}\text { Unstandardized } \\
\text { Coefficients }\end{array}$} & \multirow{2}{*}{$\begin{array}{c}\begin{array}{c}\text { Standardized } \\
\text { Coefficients }\end{array} \\
\text { Beta }\end{array}$} & \multirow[b]{2}{*}{$\mathrm{T}$} & \multirow[b]{2}{*}{ Sig. } \\
\hline & & $\mathrm{B}$ & Std. Error & & & \\
\hline \multirow[t]{6}{*}{1} & (Constant) & 3.725 & 1.954 & & 1.906 & .061 \\
\hline & TANGIBLE & .190 & .073 & .235 & 2.609 & .011 \\
\hline & RELIABILITY & .255 & .074 & .355 & 3.454 & .001 \\
\hline & RESPONSIVENESS & .082 & .070 & .105 & 1.176 & .244 \\
\hline & ASSURANCE & .273 & .084 & .370 & 3.235 & .002 \\
\hline & EMPATHY & -.088 & .090 & -.095 & -.985 & .329 \\
\hline & ent Variable: KEP & PEL & GGAN & & & \\
\hline
\end{tabular}

$\mathrm{Y}=3,725+0,130 \mathrm{X}_{1}+0,255 \mathrm{X}_{2}+0,082 \mathrm{X}_{3}+0,273 \mathrm{X}_{4}-0,088 \mathrm{X}_{5}+\mathrm{e}$

Berdasarkan persamaan regresi diatas, menunjukan bahwa koefisien regresi (tangible, reliability, responsiveness, assurance) bernilai positif, artinya kualitas pelayanan yang terdiri dari (tangible, reliability, responsiveness, assurance) berpengaruh positif terhadap Kepuasan 
Pelanggan Grab di Kota Palembang.

\subsection{Uji F (ANOVA)}

Berdasarkan tabel di bawah, menunjukan bahwa $F_{\text {hitung }}(27,339) \geq F_{\text {tabel }}(1,93)$, maka Ho ditolak dan Ha diterima artinya ada pengaruh antara kualitas pelayanan secara simultan terhadap kepuasan pelanggan dalam menggunakan jasa transportasi Grab di Kota Palembang. kesimpulan dari uji $\mathrm{F}$ ini membuktikan bahwa diantara variabel bebas, yaitu tangible, reliability, responsiveness, assurance dan empathy saling memiliki keterkaitan bersama-sama dalam mempengaruhi kepuasan pelanggan dalam menggunakan transportasi Grab di Kota Palembang.

Tabel 2. Hasil Uji Anova

\begin{tabular}{|l|l|r|r|r|r|r|}
\hline \multicolumn{2}{|l|}{ Model } & Sum of Squares & df & Mean Square & F & \multicolumn{1}{c|}{ Sig. } \\
\hline \multirow{3}{*}{1} & Regression & 128.559 & 5 & 25.712 & 27.339 & $.000^{\mathrm{a}}$ \\
\cline { 2 - 7 } & Residual & 58.309 & 62 & .940 & & \\
\cline { 2 - 7 } & Total & 186.868 & 67 & & & \\
\hline
\end{tabular}

a. Predictors: (Constant), Empathy, Responsiveness, Tangible, Assurance, Reliability

b. Dependent Variable: KEPUASAN PELANGGAN

\subsection{Uji-t (individual)}

Nilai $t_{\text {hitung }}(2,609) \geq \mathrm{t}_{\text {tabel }}(1,666)$, hal ini juga diperkuat dengan nilai signifikan $0,011<0,1$, maka Ho ditolak dan Ha diterima artinya ada pengaruh positif dan signifikan antara tangible secara parsial terhadap kepuasan pelanggan dalam menggunakan jasa transportasi Grab di Kota Palembang.

Nilai thitung $(3,454) \geq t_{\text {tabel }}(1,666)$, hal ini juga diperkuat dengan nilai signifikan $0,001<0,1$, maka Ho ditolak dan Ha diterima artinya ada pengaruh positif dan signifikan antara reliability secara parsial terhadap kepuasan pelanggan dalam menggunakan jasa transportasi Grab di Kota Palembang.

Nilai $t_{\text {hitung }}(1,176) \leq t_{\text {tabel }}(1,666)$, hal ini juga diperkuat dengan nilai signifikan $0,224>0,1$, maka Ha ditolak dan Ho diterima artinya Tidak ada pengaruh positif dan tidak signifikan antara responsiveness secara parsial terhadap kepuasan pelanggan dalam menggunakan jasa transportasi Grab di Kota Palembang.

Nilai $t_{\text {hitung }}(3,235) \geq t_{\text {tabel }}(1,666)$, hal ini juga diperkuat dengan nilai signifikan $0,002<0,1$, maka Ho ditolak dan Ha diterima artinya ada pengaruh positif dan signifikan antara assurance secara parsial terhadap kepuasan pelanggan dalam menggunakan jasa transportasi Grab di Kota Palembang.

Nilai $t_{\text {hitung }}(-0.985) \leq \mathrm{t}_{\text {tabel }}(1,666)$, hal ini juga diperkuat dengan nilai signifikan $0,329>0,1$, maka Ha ditolak dan Ho diterima artinya ada pengaruh negatif dan Tidak signifikan antara empathy secara parsial terhadap kepuasan pelanggan dalam menggunakan jasa transportasi Grab di Kota Palembang. 
Tabel 3. Hasil Uji-t

\begin{tabular}{|c|c|c|c|c|c|c|}
\hline \multirow{2}{*}{\multicolumn{2}{|c|}{ Model }} & \multicolumn{2}{|c|}{$\begin{array}{c}\text { Unstandardized } \\
\text { Coefficients }\end{array}$} & \multirow{2}{*}{$\begin{array}{c}\begin{array}{c}\text { Standardized } \\
\text { Coefficients }\end{array} \\
\text { Beta }\end{array}$} & \multirow[b]{2}{*}{$\mathrm{T}$} & \multirow[b]{2}{*}{ Sig. } \\
\hline & & B & Std. Error & & & \\
\hline \multirow[t]{6}{*}{1} & (Constant) & 3.725 & 1.954 & & 1.906 & .061 \\
\hline & TANGIBLE & .190 & .073 & .235 & 2.609 & .011 \\
\hline & RELIABILITY & .255 & .074 & .355 & 3.454 & .001 \\
\hline & RESPONSIVENESS & .082 & .070 & .105 & 1.176 & .244 \\
\hline & ASSURANCE & .273 & .084 & .370 & 3.235 & .002 \\
\hline & EMPATHY & -.088 & .090 & -.095 & -.985 & .329 \\
\hline & ndent Variable: KEP & N PELA & JGGAN & & & \\
\hline
\end{tabular}

4.4 Uji Determinasi

Tabel 4. Hasil Uji Determinasi

\begin{tabular}{|l|r|r|r|r|r|}
\hline Model & \multicolumn{1}{|c|}{$\mathrm{R}$} & \multicolumn{1}{|c|}{ R Square } & \multicolumn{1}{|c|}{$\begin{array}{c}\text { Adjusted R } \\
\text { Square }\end{array}$} & $\begin{array}{l}\text { Std. Error of the } \\
\text { Estimate }\end{array}$ & Durbin-Watson \\
\hline 1 & $.829^{\mathrm{a}}$ & .688 & .663 & .970 & 1.934 \\
\hline
\end{tabular}

a. Predictors: (Constant), Empathy , Responsiveness, Tangible, Assurance, Reliability

\section{b. Dependent Variable: KEPUASAN PELANGGAN}

Angka Adjusted R Square (nilai koefisien determinasi $\mathrm{R}^{2}$ ) sebesar 0,663 memberikan makna bahwa variabel Kualitas Pelayanan hanya mampu menjelaskan perubahan terhadap variabel Kepuasan Pelanggan Grab di Kota Palembang sebesar 0,663 atau 66,3\% sedangkan sisanya 0,337atau 33,7\% dijelaskan oleh variabel lain yang tidak termasuk dalam penelitian ini.

\section{Penutup}

Berdasarkan hasil pembahasan yang dilakukan maka hasil penelitian ini dapat disimpulkan bahwa adanya pengaruh Kualitas Pelayanan Terhadap Kepuasan Pelanggan Grab Di Kota Palembang. Hal ini dibuktikan dengan; terdapat pengaruh yang signifikan antara variabel Tangible (X1), Reliability (X2), Responsiveness (X3), Assurance (X4) dan Empathy (X5) terhadap Kepuasan Pelanggan (Y) dengan persamaan regresi linier berganda:

$Y=3,725+0,130 X_{1}+0,255 X_{2}+0,082 X_{3}+0,273 X_{4}-0,088 X_{5}+e$ 
Hasil uji $F$ menunjukan bahwa $F_{\text {hitung }}(27,339) \geq F_{\text {tabel }}(1,93)$, maka Ho ditolak dan Ha diterima artinya ada pengaruh antara kualitas pelayanan secara simultan terhadap kepuasan pelanggan. Nilai $t_{\text {hitung }}(2,609) \geq t_{\text {tabel }}(1,666)$, ada pengaruh positif variable tangible terhadap kepuasan pelanggan .Nilai thitung $(3,454) \geq t_{\text {tabel }}(1,666)$ ada pengaruh positif dan variable reliability terhadap kepuasan pelanggan. Nilai $t_{\text {hitung }}(1,176) \leq \mathrm{t}_{\text {tabel }}(1,666)$, Tidak ada pengaruh positif variable responsiveness kepuasan pelanggan Nilai $t_{\text {hitung }}(3,235) \geq t_{\text {tabel }}(1,666)$, ada pengaruh positif variable assurance terhadap kepuasan pelanggan. Nilai $t_{\text {hitung }}(-0.985) \leq \mathrm{t}_{\text {tabel }}(1,666)$, hal ini juga diperkuat dengan nilai signifikan $0,329>0,1$, maka Ha ditolak dan Ho diterima artinya ada pengaruh negatif dan Tidak signifikan antara empathy secara parsial terhadap kepuasan pelanggan dalam menggunakan jasa transportasi Grab di Kecamatan Seberang Ulu II Palembang.

Koefisien determinasi $\mathrm{R}^{2}=0,663$ (66,3\%), artinya variabel Tangible, Reliability, Responsiveness, Assurance dan Empathy memiliki pengaruh terhadap Kepuasan Pelanggan sebesar $66,3 \%$ sedangkan sisanya 0,337 atau $33,7 \%$ dipengaruhi oleh variabel lain diluar penelitian.

\section{Referensi}

Aditia, A. R. R., Wadud, M., \& DP, M. K. (2020). Pengaruh Kualitas Produk terhadap Kepuasan Konsumen Sepeda Motor NMAX pada PT Yamaha A. Rivai Palembang. Jurnal Nasional Manajemen Pemasaran \& SDM, 1(01), 23-37. https://doi.org/10.47747/jnmpsdm.v1i01.4

Amha, G. G. (2020). Determinants of Customer Satisfaction and Customer Loyalty in Amhara Credit and Saving Institute (ACSI): The Case of Waghimera Zone Sekota Town. International Journal of Marketing \& Human Resource Research, 1(01), 34-51. Retrieved from http://journal.jis-institute.org/index.php/ijmhrr/article/view/70

Aprianto, R. (2016). Pengaruh Pelayanan Terhadap Kepuasan Nasabah Pada Kantor Pt Bank Bca Cabang Lubuklinggau. Jurnal Ilmiah Ekonomi Global Masa Kini, 7(1), 11-18.

Fandy Tjiptono dan Gregorius Chandra. 2012. Pemasaran Strategik. Yogyakarta: CV Andi.

Fandy Tjiptono. 2014. Pemasaran Jasa-Prinsip, Penerapan, dan Penelitian. Yogyakarta: CV Andi.

Fandy Tjiptono. 2018. Service Management, Mewujudkan Layanan Prima.Edisi 3. Yogyakarta: CV Andi.

Fandy Tjiptono. 2019. Strategi Pemasaran. Edisi 4. Yogyakarta: CV Andi.

Hildayanti, S. K., Marnisah, L., \& Dinata, E. S. (2018). Pengaruh Nilai, Kualitas Pelayanan dan Komitmen Organisasi Terhadap Kepuasan Pelanggan Pada PT. Asuransi Kresna Mitra Tbk Cabang Palembang. Jurnal Ilmiah Ekonomi Global Masa Kini, 9(1), 61-70.

Iqbal Hasan. 2012. Pokok-Pokok Materi Statistik 2. Jakarta: PT Bumi Aksara.

Kotler dan Keller. 2009. Manajemen Pemasaran. Jilid 1, Edisi Ketiga Belas. Jakarta: Erlangga.

Nugraha, M., \& Sumadi, S. (2020). Pengaruh Kualitas Pelayanan dan Persepsi Harga terhadap Kepuasan Pasien di Rumah Sakit Type C Kabupaten Kebumen. Jurnal Ilmiah Ekonomi Global Masa Kini, 11(2), 97-102.

Oktareza, M. E. T., Halin, H., \& Handayani, S. (2020). The Effect of Service on Customer Satisfaction at PT Pandu Siwi Sentosa. International Journal of Community Service \& 
Engagement, 1(01),

19-26.

Retrieved

from

http://journal.jis-

institute.org/index.php/ijcse/article/view/74

Pribadi, G. (2020). Service Quality Sebagai Pengukuran Kepuasan Siswa dan Orang Tua/Wali Murid SMP Muhammadiyah 1 Gombong. Jurnal Ilmiah Ekonomi Global Masa Kini, 11(1), 2228.

Rambat Lupiyoadi. (2008). manajemen pemasaran jasa. Jakarta: salemba empat.

Siswanto, H., Adhilla, F., \& Purwoko, P. (2020). Analisis Pengaruh Kualitas Produk dan Kualitas Layanan terhadap Kepuasan Pelanggan Pasar Bisnis (Studi pada CV Kreasindo Mitra Pratama). Jurnal Ilmiah Ekonomi Global Masa Kini, 11(2), 92-96.

Sunyoto, Danang. (2012). Dasar-Dasar Manajemen Pemasaran Konsep,Strategi,Dan Kasus. Jakarta: Center Of Academic Publishing Service (CAPS).

Wadud, M. (2018). BAURAN PEMASARAN JASA (3 Ps: PEOPLE, PROCESS \& PHYSICAL EVIDENCE) BAGI KEPUASAN PELANGGAN. Jurnal Ilmiah Ekonomi Global Masa Kini, 8(1), 21-29.

Yanti, F., Karim, A., \& Wadud, M. (2018). Pengaruh Kualitas Pelayanan Terhadap Kepuasan Konsumen Pada Studio Ribka Foto Cabang Sekip Di Palembang. Jurnal Ilmiah Ekonomi Global Masa Kini, 8(2), 47-52. 